\title{
THE EVOLUTION OF FEDERAL/PROVINCIAL RELATIONS IN NATURAL RESOURCES MANAGEMENT
}

\author{
SUSAN BLACKMAN, JANET KEEPING, MONIQUE ROSS; \\ J. OWEN SAUNDERS $*$
}

Issues related to the management of natural resources have played an important role in federalprovincial relations over the past quarter century. Due to Alberta's position as a major producer of natural resources in Canada, the province's role in the evolution of federalism over that period has been particularly influential. In this paper, the history of federal-Alberta relations concerning energy over the past twenty-five years is reviewed, noting in particular where conflicts between the two jurisdictions have been evident, and stressing general themes where they can be distinguished.

The Alberta approach to federalism reflects a different historical context than that of the Eastern provinces as a result of its economic dependence on natural resources and its relatively recent position of affluence. The ability of the province to make full use of its resources to diversify beyond a reliance on raw energy and agricultural markets is a driving force behind the insistence on control of resource exploitation and revenues. Thus, federal measures that threaten to impinge on the province's abilities to set its own priorities have typically been regarded with some hostility. However, Alberta's approach is not only ideological but also pragmatic, and objections that might be expected on an ideological basis have been notably absent when federal actions coincide with Alberta's own immediate interests.
Depuis un quart de siècle, les questions relatives à la gestion des ressources naturelles jouent un rôle important dans les relations fédérales-provinciales. Compte tenu du rang privilégié qu'elle occupe dans le secteur des ressources naturelles au Canada, l'Alberta a joué un rôle particulièrement déterminant dans l'évolution du fédéralisme pendant cette période. Le présent article examine l'histoire des rapports entre le gouvernement fédéral et l'Alberta au cours des vingt-cinq dernières années; il relève certains conflits de compétence et souligne les thèmes généraux qui permettent d'établir des distinctions.

L'attitude de l'Alberta envers le fédéralisme reflète un contexte historique différent de celui des provinces de l'Est - une économie tributaire des ressources naturelles et une prospérité relativement récente. L'Alberta doit pouvoir tirer pleinement parti de ses ressources pour diversifier son économie et évoluer au-delà de sa dépendance vis-à-vis des marchés des ressources énergétiques et agricoles. II est donc impératif qu'elle contrôle l'exploitation de ses ressources et les revenus qu'elle en tire. C'est pourquoi les mesures fédérales qui risquent d'empêcher la province d'établir ses propres priorités sont accueillies avec une certaine hostilité. Pourtant, l'approche de l'Alberta n'est pas seulement idéologique mais aussi pragmatique; et les objections idéologiques auxquelles on pourrait s'attendre sont notablement absentes quand les décisions fédérales coïncident avec les intérêts immédiats de l'Alberta.

\section{TABLE OF CONTENTS}

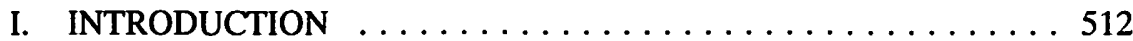

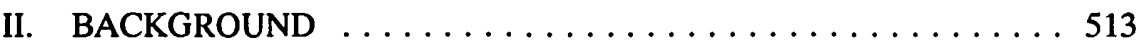

III. ENERGY WARS AND CONSTITUTIONAL

STRUGGLES: $1973-85 \ldots \ldots \ldots \ldots \ldots \ldots \ldots \ldots \ldots \ldots \ldots$

A. THE ENERGY WARS $\ldots \ldots \ldots \ldots \ldots \ldots \ldots \ldots \ldots$

B. CONSTITUTIONAL PATRIATION $\ldots \ldots \ldots \ldots \ldots \ldots . \ldots 521$

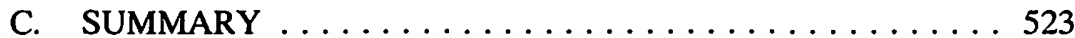

IV. FREE TRADE AND NATURAL

RESOURCES MANAGEMENT ................

- Research Associates, Canadian Institute of Resources Law.

.. Executive Director, Canadian Institute of Resources Law and Adjunct Professor, Faculty of Law, the University of Calgary. 
V. THE STRUGGLE FOR ENVIRONMENTAL CONTROL . . . . 526

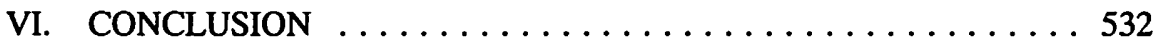

\section{INTRODUCTION}

The past quarter century has seen a continuing debate concerning the role of natural resources in Canadian federalism. This is not the first time that natural resources have played a role in federal-provincial relations. In the Western provinces, the extent of federal control and ownership was a primary irritant in relations with Ottawa from the beginning. However, the actions of the federal and provincial governments with respect to natural resources management have never in the past garnered so much popular attention as a matter of national public policy.

One reason for the increased public interest can be traced to the direct effects such matters have had on the lives of ordinary Canadians. With the dramatic increases in the price of energy beginning in 1973, ownership of natural resource revenues became more than just a matter of constitutional theorizing; it had immediate and significant implications for people's pocketbooks. Similarly, in the late 1980s and continuing into the present decade, Canadians' growing concerns over their environmental future have translated into a debate over the mandates that different levels of government should assume under the current constitutional structure.

Issues related to natural resources management have figured importantly as items on both national and international public policy agendas. Even so, the intergovernmental rivalries in Canada on these matters have been characterized by a particularly acrimonious debate. This may be accounted for by the special position that natural resources have held in Canadian federalism. Historically, the ability to draw on the revenues accruing from provincial ownership of resources was vital to the very viability of the province as a fiscal entity. It is perhaps not surprising, then, that the belief in the overriding interests of the province in this area should come from the West, which had to struggle to attain control over its resources, and continues to depend most heavily on the revenues which derive from them. In recent years, the possibility of federal control of certain environmental aspects of hydroelectric development has also made this a lively issue in Quebec.

This essay examines federal-provincial relations over the past twenty-five years, as reflected in issues relating to natural resources management. Of necessity this means that we have been selective in our discussion of federalism; there will be found no discussion, for example, of such high-profile events as Meech Lake, where the issue of jurisdiction over natural resources did not play a central role. Moreover, the perspective taken here is Western - and indeed, Albertan. Whether or not one agrees with the positions taken by Alberta over this period, it has played a role in the development of this area of Canadian federalism that is far out of proportion to its size. Although to many Canadians this high-profile stance seemed to be the obvious and direct result of the dramatic changes in the world oil market - and of the concomitant change in Alberta's economic fortunes - the positions taken by Alberta with respect to natural resources management should more properly be viewed as part of a broader continuum. That wider context is the subject of the first section of this essay. Having set the context, we then turn to a discussion of 
how Alberta's historical positions with respect to natural resources were reflected in the so-called "energy wars" and constitutional negotiations of the 1970s and early 1980 s. Following this, we then briefly discuss the Alberta position on free trade, where one finds a remarkable - although in some respects ironic - concordance of federal and Alberta interests. From this period of federal-provincial harmony we turn to an issue that has given rise once again to a significant divergence in positions, the question of environmental responsibility. Finally, we offer some thoughts as to the general themes one can draw from the experience of the past twenty-five years of Alberta-federal relations with respect to natural resources management, focusing on whether there is indeed an "Alberta approach" to federalism.

\section{BACKGROUND}

Going back twenty-five years, one would find oneself in the midst of a ten year period (1962-72) which has been characterized as "the calm before the storm" in federal-Alberta relations. ${ }^{1}$ During that period the Western Canadian oil and gas industry enjoyed rapid expansion in conjunction with "quiet regulatory consolidation."2 Perhaps the years are better seen as an anomalous lull in an otherwise on-going dispute for, from their inception, the prairie provinces have been acutely concerned with first obtaining and then exercising jurisdiction over natural resources within their boundaries.

Although Alberta and Saskatchewan were created as provinces in 1905, it was not until 1930 that they (and the earlier-formed Manitoba) were given jurisdiction over natural resources so as to put them on par with the original provinces. ${ }^{3}$ This delay gave rise to much consternation in the Western provinces where there was significant agitation for the transfer of authority over natural resources. When jurisdiction over resources was finally obtained, Alberta began the process of exercising those powers.

The most urgent concerns in 1930 with respect to oil and gas centred on physical conservation of the resources. The Turner Valley field was being rapidly depleted by furiously unregulated drilling for oil and the flaring of vast quantities of natural gas. In Prairie Capitalism, Richards and Pratt note that "Calgarians could sit on their front porches on a summer's night and read their papers by the glow of the flares thirty miles away. ${ }^{n 4}$ The wasteful chaos led to the creation of the Turner Valley Conservation Board in 1932, which after several metamorphoses became the present day Energy Resources Conservation Board.

It was not until the discovery of significant quantities of oil at Leduc in 1947 that a period of jurisdictional maneuvering over oil and gas began. The Alberta government was

1 The term is used several times by G.B. Doern \& G. Toner in The Politics of Energy: The Development and Implementation of the NEP (Toronto: Methuen, 1985).

Ibid.

The natural resource agreements with the prairie provinces can be found as schedules to the Constitutional Act, 1930, Appendix II, No. 26.

4 J. Richards \& L. Pratt, Prairie Capitalism: Power and Influence in the New West (Toronto: McClelland and Steward, 1979) at 46-47. 
keen to use oil and gas development as a springboard to escape from a precarious dependence on agriculture. The federal government was equally eager to make the most of the discoveries - in particular, the West's natural gas - to build the country. The first move was made by Ottawa in 1949 with introduction of a Pipelines Act, ${ }^{5}$ pursuant to which the federal government prepared to exercise control over all interprovincial and international oil and gas pipelines in the country. Later the same year, Alberta responded with The Gas Resources Preservation Act, ${ }^{6}$ which required a permit for the removal of gas from the province and ensured that Albertans would have priority claims on gas when amounts were insufficient to satisfy both domestic and export needs. Although the constitutionality of the statute was always in doubt, the Alberta government persevered with the legislation:

Unsure of its constitutional power to restrict the removal of gas but fearful that federally incorporated pipeline companies, most of them controlled by American interests, would try to make individual arrangements with the major producers, in July 1949 at a stormy special session of the legislature... the Manning government pushed through several new pieces of legislation, including the Gas Resources Preservation Act, greatly strengthening its wellhead control over gas. ${ }^{7}$

Some attributed Manning's enthusiasm for the legislation to a strong interest in exporting gas from the province (something which was vigorously opposed by many Albertans at the time) ${ }^{8}$ The better view, however, is that Manning and his government saw the move as necessary to prevent control of the province's natural gas from passing to nonAlbertans:

In fact, Manning appears to have been reacting defensively to a fear of outside encroachment, such encroachment being the classic motivation for provincial state intervention in Alberta. Social Credit had moved to protect its jurisdiction only after failing to convince the federal Liberal government to insert protective clauses in federal pipeline legislation requiring provincial permission before gas could be exported. ${ }^{9}$

Alberta's next move was to create a province-wide gathering system for natural gas which was part publicly and part privately controlled: in 1954 Alberta Gas Trunk Line ("AGTL") was formed. This development, too, was motivated by the fear of losing control over the province's natural resources:

Fear of outside monopoly under federal jurisdiction was behind the enactment of the Gas Resources Preservation Act in 1949, and it was also the dominant consideration underlying the idea for a provincial monopoly over gas-gathering within the province. A single integrated gathering system would act as a common carrier inside Alberta, distributing pooled gas to export companies... at the provincial border.

The statute was not enacted until 1952. See R.S.C. 1952, c. 211.

S.A. 1949 (Second Session), c. 2.

Supra note 1 at 133.

Ibid. at 65.

Ibid. 
This would keep the export companies - and Ottawa - out, and prevent encroachments on the province's jurisdiction. ${ }^{10}$

The next few years were busy ones at the federal level. In 1956, the decision was made to build the Trans-Canada natural gas pipeline, and in 1957, a Royal Commission on Energy (the "Borden Commission") was struck to study a number of energy issues. ${ }^{11}$ It has been said that the primary legacy of the Borden Commission was twofold: creation of the National Energy Board in 1959, and adoption of the National Oil Policy in 1961.

As a precursor to the National Oil Policy ("NOP"), the federal government had decided against a proposal by the Canadian independents, led by Home Oil, to build an oil pipeline from Edmonton to Montreal. It preferred that Montreal continue to be served by offshore imports of oil. Hence the essence of the NOP: a line was drawn at the Ottawa Valley. The provinces west of the Ottawa Valley (that is Ontario and west) would receive crude oil from Canadian (largely Albertan) fields. Consumers east of the line would be supplied by imports.

In the light of later energy battles, the NOP is now seen as "surprisingly noncontroversial." 12 The federal Liberal party supported it. The Eastern provinces were content to receive cheaper offshore oil. For the producing provinces, the policy represented a guaranteed market, providing - most importantly - sure access to Ontario consumers. Although the NOP divided the country in two for the purposes of crude oil supply, it "also strengthened national integration to the extent that it caused the forced integration of Ontario markets with Alberta oil fields." ${ }^{13}$

And so a decade (1962-1972) of relative tranquillity in energy matters was begun. Most of those concerned with Canada's oil and gas industry shared a common objective: rapid production of the resources. Since these resources were viewed as virtually limitless, there was no reason for the federal and provincial governments to battle over jurisdiction.

There is evidence of this intergovernmental consensus over resource development in the agendas of two major constitutional conferences of the period. The first was the "Confederation of Tomorrow" conference called by the Province of Ontario to mark the centennial of Confederation. Alberta's representations to the conference, as recorded in the proceedings, make no reference to unhappiness about the division of powers over natural resources, or their manner of exercise by the federal government. ${ }^{14} \mathrm{~A}$ second constitutional conference of the period was the Victoria conference, which was devoted to issues of constitutional change, such as a new amending formula. Jurisdiction over natural resources did not play a role in it either. ${ }^{15}$ This relative harmony disguised the

Ibid. at 66.

The Royal Commission on Energy issued its First Report in 1958 and its Second Report in the following year.

Supra note 1 at 133.

Ibid.

See Proceedings, The Confederation of Tomorrow Conference, Toronto, 27-30 November 1967.

See Constitutional Conference Proceedings, Victoria, British Columbia, 14-16 June 1971. 
latent conflicts that would emerge given the catalyst of a divergence of interests following the OPEC oil embargo of 1973. Domestically, the debates surrounding constitutional patriation in the late 1970s and early 1980s were another catalyst for a re-examination of the appropriate roles of the two levels of government in this area.

\section{ENERGY WARS AND CONSTITUTIONAL STRUGGLES: 1973-85}

\section{A. THE ENERGY WARS}

In late 1973, OPEC initiated an oil embargo against the United States and the Netherlands. In Canada, the federal government's ability to respond quickly and effectively with appropriate changes in energy policy was severely limited, both because it had no direct access to information, and because it had very few personnel with appropriate expertise. Therefore, it "predictably reeled from crisis to crisis in 1973 and 1974."16 When world oil prices increased sharply, the federal government reacted with drastic measures aimed at keeping the domestic price down, and even considered imposing oil rationing. ${ }^{17}$

The events in 1973 brought oil pricing, and the division of oil revenues, to the fore as a major contentious issue between the Alberta and federal governments. ${ }^{18}$ The federal government froze the domestic price of oil in September 1973, and imposed a tax on oil exports to the United States. Alberta perceived the tax as an intrusion into its jurisdiction. ${ }^{19}$ Subsequently, at a First Ministers' Conference on Energy in January 1974, Premier Lougheed forcefully stated Alberta's position:

It is clear and unequivocal that the Fathers of Confederation decided that the natural resources within provincial boundaries would be owned by the citizens through their provincial governments, rather than through the federal government. Implicit in such ownership is the right of the provinces to manage the resources in terms of conserving or selling them. Perhaps the Fathers of Confederation envisioned this conference when they recognized that the power of the Federal Government and the influence of the central Canadian population concentration could be balanced by the resource ownership of the less populated regions of Canada....

We view the federal export tax on Alberta oil as contrary to both the spirit and the intent of Confederation. We object to it in principle because it is discriminatory. It is not just an export tax - it is also a price freeze on all of Alberta's production at immense cost to Albertans.... ${ }^{20}$

\section{$16 \quad$ Supra note 1 at 91.}

$17 \quad$ Ibid.

18 See P. Tyerman, "Pricing of Alberta's Oil" (1976) 14 Alta. L. Rev. 427 at 428.

19 "Alberta Premier Peter Lougheed charged Ottawa with discrimination and bad faith...Lougheed saw the export tax as more than an appropriation of revenue from the provincial treasury. He saw it as a move to grab control of resources from the provinces." Ibid. 
Partly in retaliation to the export tax, Alberta raised the royalties payable from production on Crown lands. ${ }^{21}$ This move was blocked in the federal budgets of May and October 1974 when the tax deduction hitherto available for royalty payments was disallowed. Faced with a widespread slowdown in exploration, Alberta was forced to lower the royalties. ${ }^{22}$

In order to increase its control of Crown-owned resources, Alberta enacted legislation in 1973 setting up a commission to market the Crown's royalty share of oil production..$^{23}$ In 1975, the Alberta Petroleum Marketing Commission ("APMC") became the exclusive agent for marketing all oil production from Alberta Crown lands ${ }^{24}$ and its jurisdiction was expanded to include natural gas. Although provision was made for the APMC to set prices unilaterally, ${ }^{25}$ from 1974 to 1985 (except for a period in 1980), natural gas prices were set by federal-provincial agreement. ${ }^{26}$

In January 1974, a new oil price was agreed upon at the Federal-Provincial First Ministers Conference on Energy. In April 1975, at another such conference, agreement was not achieved, but the federal government was convinced by the producing provinces that price increases were necessary. ${ }^{27}$ In 1975 , the federal government passed the Petroleum Administration $\mathrm{Act}^{28}$ which gave it the power either to set oil and gas prices through agreements with producing provinces or to set them unilaterally. Thereafter, the federal government and Alberta negotiated bilateral pricing agreements, and oil and gas prices were permitted to rise quickly until 1980, though they did not reach world levels. ${ }^{29}$

According to Tyerman, Alberta had the following objectives during this dispute:

- to keep control over the province's resources,

- to get as high a price as possible for Alberta's oil,

- to encourage the oil industry to search for new discoveries in Alberta. ${ }^{30}$

21

A. Walker, "The National Energy Program: An Overview of Its Impact and Objectives" in G.C. Watkins \& M.A. Walker, eds., Reaction: The National Energy Program (Vancouver: The Fraser Institute, 1981) 3 at 23. The province owns between $80 \%$ and $85 \%$ of the oil and gas reserves within its borders. See H.T. Emergy, "Some Legal Aspects of Oil Developments in Alberta" (1950) 28 Can. Bar Rev. 1071; B.W. Semkow, "Energy and the New Constitution" (1985) 23 Alta. L. Rev. 101 at 110.

Supra note 1 at 93 . The total of provincial royalties and federal taxes in some cases exceeded $100 \%$ of the producers' income; see supra note 21.

Petroleum Marketing Act, S.A. 1973, c. 96. The APMC takes delivery of the Crown's royalty share of production and markets it.

Since deregulation, the APMC no longer has exclusive authority to market the lessee's share of production.

Natural Gas Price Administration Act, S.A. 1975, c. 70.

Natural Gas Pricing Agreement Act, S.A. 1975, c. 38.

D.V. Smiley, Canada In Question: Federalism in the Seventics, 2d ed. (Toronto: McGraw-Hill Ryerson, 1976) at 149.

S.C. 1974-75-76, c. 47. This statute later became the Energy Administration Act, R.S.C. 1985, c. E-6.

Supra note 1 at 93.

Supra note 18 at 433. 
The federal government's objectives on the other hand were:

- to achieve a single price for oil in Canada,

- to shelter Canadian consumers from high world oil prices,

- to encourage exploration for and development of new sources of oil in Canada,

- to make Canada self-sufficient in oil in the future. ${ }^{31}$

However different the two sets of objectives might seem, the real source of contention was pricing. ${ }^{32}$ In 1977 and 1978, two cases were decided at the Supreme Court of Canada which clarified the constitutional background underlying this debate. Although both these cases arose in Saskatchewan, they raised issues that went to the heart of Alberta's concerns about its ability to manage its natural resources.

After the rise in world oil prices in 1973, Saskatchewan attempted to capture some of the windfall gains accruing to oil companies through the imposition of a mineral income tax on freehold lands and a royalty surcharge on Crown lands. Both these charges were imposed at the wellhead and were designed to capture all of the increase in the wellhead price. In Canadian Industrial Gas and Oil Ltd. v. Saskatchewan, ${ }^{33}$ this regulatory scheme was challenged as ultra vires the province on the basis that:

1. it constituted indirect taxation, a power not within provincial legislative competence, since s. 92(2) of the Constitution Act, 1867 restricted provinces to direct taxation;

2. it related to interprovincial and international trade, a matter over which the federal government had exclusive legislative power under s. 91(2) of the Constitution Act, 1867.

The Supreme Court of Canada agreed with the plaintiff. Since almost all of Saskatchewan's oil and gas production was destined for export, the court characterized the tax and surcharge as an export tax, a form of indirect taxation. Additionally, the legislation effectively gave the government the power to fix the price of production. Since most of the production was exported, the scheme involved the regulation of interprovincial trade, a matter under the exclusive jurisdiction of the federal parliament.

Soon after this case, provincial efforts to influence trade were again attacked in Central Canada Potash v. Saskatchewan. ${ }^{34}$ A provincial scheme permitted each potash producer to produce and sell a portion of its total productive capacity. Only after every producer had sold its share, could permission to produce and sell more potash be obtained. A floor price for potash was also part of the scheme. Because the potash was almost totally exported from the province, the scheme was found to be ultra vires, on the basis that 
provincial legislative authority did not extend to the marketing of provincial products outside the province.

Against this backdrop, relations between the federal and Alberta governments took a dramatic downturn in 1979 and 1980. In 1979, the world price of oil doubled and it became obvious that the prevailing approach to energy prices would no longer work:

The federal government renounced its policy of linking domestic prices to world prices. This not only left Canadian prices far below international ones, but also cooled the already difficult relations between Alberta and the federal government. ${ }^{35}$

Upon the return to power of the Liberal Party under Prime Minister Trudeau in 1980, a new energy Minister was appointed. Marc Lalonde was a strong individual with great influence over energy policy development at a time when the Prime Minister was less involved because of simultaneous constitutional negotiations. By contrast, in Alberta, Premier Lougheed preferred to keep personal control over energy matters. It has been argued that this left his energy Minister in a less able negotiating position. ${ }^{36}$

In 1980, in the absence of an agreement on pricing, the federal government moved unilaterally to set oil prices and impose new tax measures. Although arguably done to promote Canadian energy self-sufficiency, ${ }^{37}$ this move could also be characterized as a revenue grab. ${ }^{38}$ With rising oil prices, Alberta had become a very rich province. The formula for calculating federal government equalization payments required division of the provinces into "have" and "have-not" provinces. As Alberta became rich, Ontario for the first time ever became a have-not province. ${ }^{39}$ The equalization payments owed to populous Ontario threatened to impose severe financial strains on the federal government. $^{40}$

The National Energy Program ("NEP") was introduced by the federal government in October 1980. It included measures designed to accelerate exploration and development in the offshore area, promote oil conservation by switching to other forms of energy, and promote Canadian ownership in the petroleum industry. It also unilaterally imposed a schedule of small staged increases in the prices of oil and natural gas, and put a wellhead tax on natural gas. Additionally, it set a production tax on oil and gas revenues ("PGRT"). ${ }^{41}$ By the federal government's own calculations, the NEP would increase its share of resource revenues to twenty-six percent in the first three years of the program,

Supra note 1 at 93.

Ibid. at 44-46.

N. McDougall, Fuels and the National Policy (Toronto: Butterworths, 1982) at 148.

This was the interpretation of the province of British Columbia: supra note 1 at 106.

J. Courchene, "The National Energy Program and Fiscal Federalism: Some Observations" in Watkins \& Walker, eds., supra note 21,77 at 85.

H. Norrie \& D. Ouram, A History of the Canadian Economy (Toronto: Harcourt Brace Javanovich, 1991) at 614.

See H. Norrie, "Energy, Federalism and the West" in Waller et al., eds., Canadian Federalism: From Crisis to Constitution (Boston: University Press of America, 1988) 173 at 181; A. Carmichael \& K. Stewart, Lessons from the National Energy Program (Toronto: C.D. Howe Institute, 1983) at 7. 
while the provincial share would drop from fifty percent to forty-one percent, and the industry share would drop from forty-one percent to thirty-three percent. ${ }^{42}$ Not unexpectedly, the NEP provoked a bitter reaction from the Alberta government, which moved to cut production of oil going to Eastern Canada. Alberta began a court challenge to the new taxes and withheld approval for two major oil sands projects. ${ }^{43}$

Economic studies have since concluded that the NEP and Alberta's reaction to it were extremely costly to Canadians. ${ }^{44}$ By the summer of 1981 , oil industry activity had decreased substantially because of the production cutbacks and the negative impact of the NEP taxes on cash flow. Uncertainty caused by the political impasse affected investment in Canada. ${ }^{45}$ Renewed bargaining led to another federal-provincial agreement in September $1981,{ }^{46}$ in which prices were permitted to rise much more quickly. Federal taxes were also increased in the agreement. However, by 1982, the new cash flow expected to follow from the agreement had not materialized, owing to higher taxes and to a number of external factors (including, generally, a softening in world demand in the face of increased conservation measures and a world-wide recession, and a glut on world oil markets, accompanied by a decrease in prices). ${ }^{47}$

The federal government's continuing equalization payment problem was solved in 1982 by amending the equalization formula so as to leave out both the richest and the poorest provinces when calculating average provincial revenue. By leaving out Alberta, Ontario once again became a "have" province. ${ }^{48}$ However, deteriorating conditions in the industry led to demands on both levels of government to ease the tax burden. Some federal and provincial measures, including royalty reductions, tax suspensions, grants, credits, and price increases, were instituted to this end in 1982 and 1983. The September 1981 agreement was amended in June of 1983 to freeze the domestic price of oil, with the condition that it would be permitted to rise if it went below seventy-five percent of the world price and fall if it exceeded the world price. ${ }^{49}$

In 1982, Alberta's court challenge to the NEP was finally decided by the Supreme Court of Canada. In Reference Re Proposed Federal Tax on Exported Natural Gas, ${ }^{50}$ Alberta put forward this scenario: it would retain ownership of its gas and contract out production and transport of the gas to a company. The province would remain the owner of the gas until it was sold to a U.S. purchaser. The majority of the Court held that the gas was immune from taxation by the federal government by virtue of $s .125$ of the Constitution Act, 1867, which "protect[s] the lands and property of one level of

Carmichael \& Steward, ibid.

Ibid. at 8; supra note 1 at 106.

Carmichael \& Steward, ibid. at 9.

Ibid. at 10.

Norrie, supra note 41 at $182-83$.

Supra note 1 at 113-14.

Supra note 40.

See supra note 1 at 113-18. See also, Agreement to Amend the Memorandum of Agreement of 1 September 1981 between Canada and Alberta Relating to Energy Pricing and Taxation, 30 June 1983. 
government from incursion by way of taxation by the other level of government. ${ }^{\text {51 }}$ Ownership of property by the province:

necessarily carries with it the right of the province to the proceeds of disposition ... the immunity is not lost merely because the Province of Alberta was engaged in the simple removal and transportation of natural gas in its natural unprocessed state. ${ }^{52}$

It should be noted, however, that the fact situation addressed by the courts in this case was highly unusual, since the provincial Crown normally disposes of its oil and gas reserves by way of a lease in which the property in the resource is transferred. The case consequently has little practical value unless Alberta were to engage in a wholesale restructuring of its scheme for disposing of interests in natural gas.

If there was any life left in the energy wars of the 1970 s and early 1980 s, it was effectively extinguished in September 1984 with the election of a Conservative federal government. Partly because the new federal government was then ideologically close to the Alberta government, but also because of the dramatically changed nature of world oil markets, an agreement to deregulate oil and gas pricing was reached quickly. ${ }^{53}$ Federalprovincial energy wars survived only in occasional rhetorical echoes of earlier confrontational days. ${ }^{54}$ The accommodation thus achieved left unresolved the underlying legal questions posed by the federal-provincial battles surrounding initiatives such as the National Energy Program. As with so many other federal-provincial conflicts in Canada, the resolution was achieved in the political rather than judicial arena.

\section{B. CONSTITUTIONAL PATRIATION}

The federal-provincial confrontations over energy policy were largely coincident with another major event in the history of federal-provincial relations - the amendment of Canada's Constitution in 1982. Not surprisingly, given the sensitivities at the time regarding the nature of federal actions in the energy sector, natural resources management became an issue on the agenda for constitutional reform. Specifically, this reform process added s. $92 \mathrm{~A}$ — the resource amendment — to the Constitution Act, 1867, and a formula for future constitutional amendments. ${ }^{55}$ Alberta and Saskatchewan took the lead through

Ibid. at 422 .

Ibid. at 445-46. Note that the court did not decide whether the immunity would have been lost had provincial property been processed substantially before sale.

See Energy Pricing and Taxation Understanding Between Canada, Alberta, British Columbia and Saskatchewan, 26 March 1985 [hereinafter "Western Accord"]. This agreement was followed on 31 October 1985 by the Agreement Among the Governments of Canada, Alberta, British Columbia and Saskatchewan on Natural Gas Markets and Prices (Edmonton: The Ministry, 1985) [hereinafter "Hallowe'en Agreement"].

For example, in the statement of Alberta's Energy Minister upon introducing the Western Accord to the Alberta Legislature: "The NEP was a clear and unacceptable intrusion on the ownership rights of Albertans in our petroleum resources..." Alberta Legislature, Alberta Hansard, (28 March 1985) at 239 (Zaozinny).

See Constitution Act, 1982, being Schedule B to the Canada Act 1982 (U.K.) 1982, c. 11, ss. 38-48 [hereinafter Constitution Act, 1982]. 
the $1970 \mathrm{~s}$ in pressing the issue of legislative authority over natural resources at constitutional negotiations. Both provinces put forward a list of requirements, although it was Saskatchewan that first put forward s. 92A. Alberta, for its part, proposed protection for provincial legislative and proprietary rights in the amending formula. ${ }^{56}$

Five issues predominated in the constitutional discussions with respect to s. 92A:

1. the definition of natural resources;

2. the definition of primary production;

3. federal jurisdiction over trade and commerce in relation to natural resources;

4. provincial access to indirect taxation of natural resources; and

5. the federal government's power to declare ${ }^{57}$ works and undertakings in relation to resources to be for the general advantage of Canada. ${ }^{58}$

The resource amendment was discussed by First Ministers at a constitutional conference in February 1979, where a draft was tabled. The draft dealt with provincial legislative authority over resource development, taxation of resources, and provincial control over export of resources with limitations on the federal government's paramount power over interprovincial and international trade and commerce. ${ }^{59}$ The declaratory power was not addressed.

At the February 1979 conference, Alberta and Saskatchewan focused their concerns on interprovincial trade in resources. They agreed that federal paramountcy over interprovincial trade and commerce had to be limited but disagreed on how to do so. The conference finished with no discussion of other aspects of the resource amendment and no agreement. During the conference, Alberta also tabled its proposal for changing the amending formula, which became known as the "Alberta formula". 60

After the February 1979 conference, relations between the federal government and the provinces deteriorated. At an acrimonious conference in September 1980, the federal government replaced the 1979 draft of s. 92A with a more limited version. No agreement was reached and, on October 2, 1980, the Prime Minister announced that the federal government would proceed unilaterally to patriate and amend the Constitution. Subsequently, a resolution was introduced in Parliament to patriate the Constitution and

See Alberta Legislature, Alberta Hansard, (20 October 1980) at 1148 (Premier Peter Lougheed). Pursuant to Constitution Act, 1867, (U.K.), 30 \& 31 Vict., c. 3, s. 92(10)(c) [hereinafter Constitution Act, 1867].

J. Meekison, et al., Origin and Meaning of Section 92A of the 1982 Constitutional Amendment on Resources (Montreal: The Institute for Research on Public Policy, 1985) at 15. For example, in relation to the declaratory power, an exercise of the federal government's power to declare oil wells to be a work or undertaking for the general advantage of Canada would transfer all oil wells in Canada from provincial legislative jurisdiction to federal legislative jurisdiction.

The text of the draft presented at the February 1979 conference is reproduced in Appendix A in W.D. Moull, "Section 92A of the Constitution Act, 1867" (1983) 61 Can. Bar Rev. 715 at 733-34. Alberta Legislature, Alberta Hansard, (10 November 1981) at 1569 (Johnston). 
the Prime Minister set about negotiating with opposition parties and provinces to obtain support. $^{61}$

In response, Alberta joined other provinces in a court challenge. In the resulting decision, ${ }^{62}$ the Supreme Court of Canada held that, although the federal government's unilateral action was legal, it was unconstitutional in that it went against Canadian constitutional conventions and offended federalism. Subsequently, in the renewed negotiations, the resources amendment faded in importance before the issue of the amending formula. At the last conference in November 1981, the federal version of $\mathbf{s}$. 92A prevailed; however, Alberta's version of the amending formula was accepted. ${ }^{63}$

The amending formula, as passed, permits provinces to dissent from any constitutional amendment that will derogate from the "legislative powers, the proprietary rights or any other rights or privileges of the legislature or government of a province." If a province dissents, the amendment will have no effect until that province revokes its dissent. ${ }^{64}$

The final version of $s .92 \mathrm{~A}^{65}$ affects provincial powers in the following ways: it confirms the provinces' exclusive legislative authority over exploration, development, conservation and management of non-renewable resources and it gives provinces new jurisdiction to impose indirect taxation on resources, provided the taxes do not discriminate between provinces. It also gives provinces new jurisdiction over interprovincial trade in resources, provided that there is no discrimination in price or supply among provinces, and that federal legislation in the same area is paramount. Section 92A, as passed, has no effect on federal legislative powers.

\section{SUMMARY}

Between 1973 and 1985, Alberta clearly and consistently asserted its historic belief that natural resources are a matter of provincial jurisdiction, as regards both legislative competence and resource ownership. The only act that seemed somewhat inconsistent with this position was Alberta's apparently minor interest in s. 92A. However, if Alberta's petroleum legislation was fully supported by its proprietary powers, ${ }^{66}$ then additional legislative powers over the same subject matter might be considered unnecessary. Alberta's primary interest lay in interprovincial trade. If an independent proprietary power could support trade legislation, it was still liable to be whittled away by federal legislative jurisdiction over interprovincial trade ${ }^{67}$ - hence Alberta's interest in curtailing federal jurisdiction in that area at the February 1979 Conference.

Supra note 58 at 23-27.

A.G. Man. v. A.G. Can. (Reference re Amendment of the Constitution of Canada), [1981] 1 S.C.R. 753.

Supra note 58 at 28.

Constitution Act, 1982, supra note 55, ss. 38(2), (3).

Constitution Act, 1867, supra note 57, s. 92A.

That proposition is arguably uncertain. See Semkow, supra note 21 at 107-09.

See ibid. at 109. 
Ultimately, however, the increased legislative powers granted by s. $92 \mathrm{~A}$ were in danger if the Constitution could be amended to affect provincial legislative or proprietary powers without the consent of the affected provinces. Therefore, the amending formula became the focus of concern as it presented the most effective means of forestalling future federal initiatives to control the management of natural resources.

\section{FREE TRADE AND NATURAL RESOURCES MANAGEMENT}

The period of relative harmony that characterized Canada-Alberta relations beginning with the election of the federal Conservative government in 1984 reached its high-water mark with the decision to enter into negotiations with the United States on a comprehensive free trade agreement. The free trade negotiations gave rise to some interesting alliances, including strong support for the federal proposals from both Quebec and Alberta, although the agreement significantly limits the economic actions that provinces can take in support of their own industries. The Canada-U.S. Free Trade Agreement ("FTA") ${ }^{68}$ that ultimately emerged, and its implications for the energy and natural resources sector, have been addressed in detail elsewhere. ${ }^{69}$ However, the FTA will be discussed here briefly with respect to its implications for federal-provincial relations regarding natural resources management.

Given Alberta's historical insistence on the right to manage its own natural resources, the province's wholehearted embrace of free trade contains at least some element of irony. The FTA imposes some significant restrictions on Alberta's ability to manage its natural resources, and particularly (under Chapter Nine) its energy resources. For example, past practices with respect to subsidizing the growth of the petrochemicals industry through preferential access to natural gas feedstock ${ }^{70}$ would violate the non-discrimination provisions for energy prices in the FTA (quite apart from being subject to U.S. countervailing duties on the basis of export subsidization). Similarly, it could be argued that the practice of requiring removal permits for exporting natural gas from the province under the Gas Resources Preservation Act - a practice which has been referred to earlier as constitutionally suspect, and which has been used as a means of imposing minimum export prices for natural gas ${ }^{71}$ - would be in violation of the FTA. ${ }^{2}$

External Affairs Canada, Canada-United States Free Trade Agreement, 10 December 1987, in force 1 January 1989; implemented in Canada by the Canada-United States Free Trade Agreement Implementation Act, S.C. 1988, c. 65, and in the United States by the United States-Canada Free Trade Agreement Implementation Act Pub. L. No. 100-449 (1988).

See S.P Battram \& R.H. Lock, "The Canada/United States Free-Trade Agreement and Trade in Energy" (1988) 9:2 Energy L.J. 327; A. Hudec \& J. Quinn, "Energy Aspects of the Canada-United States Free Trade Agreement" (1989) 2 Can. Pet. Tax J. 1; J.O. Saunders, "Energy, Natural Resources and the Canada-United States Free Trade Agreement" (1990) 8:1 J. Energy \& Nat. Res. L. 3 [hereinafter "Energy"]; J.O. Saunders, "The Mexico Factor in North American Free Trade: A Canadian Perspective" (1991) 9:4 J. Energy \& Nat. Res. L. 239.

The practice is discussed in C. Yoder, "United States Countervailing Duty Law and Canadian Natural Resources" in J.O. Saunders, ed., Trading Canada's Natural Resources (Calgary: Carswell, 1987) 81 at 89.

$7 \quad$ See "Energy", supra note 69 at 9.

$n$ Article 902 (2) prohibits the imposition of minimum export prices. 
Such subsidization practices might have been attacked in the United States by the imposition of countervailing duties without the FTA, and it is conceivable that, in certain circumstances, Alberta would be willing to accept such a price as the cost of diversifying its economy. With the advent of the FTA, however, the province must contemplate the further possibility that the federal government, acting under its trade and commerce power, might prohibit such actions where it deemed that they would imperil the agreement as a whole.

It should be emphasized that the very existence of the FTA arguably extends validity to possible federal actions, which, if attempted without the backdrop of the FTA, might be considered ultra vires. Essentially, the argument is that the FTA is an indivisible package, and that while some of its aspects considered individually might be open to constitutional challenge, when considered as part of a broader scheme dealing with international trade, any intrusion on provincial powers would be merely incidental. There has been considerable debate over the scope which courts will give to the federal trade and commerce power. Professor Gibson, a leading constitutional authority who "is apprehensive about the consequences of free trade," concludes that "if the courts apply standard principles of Canadian constitutional law, the FTA and its full implementation will likely be found to fall squarely within the domain of the government and Parliament of Canada." ${ }^{173}$ Perhaps even more striking, in light of the historical positions of Alberta and Quebec toward federal intrusions on provincial powers, is Professor Gibson's assertion that "the opportunity that the FTA presents to the federal authorities to impose a uniform economic model...on all the provinces should be profoundly disturbing to anyone who values federalism." ${ }^{74}$

In view of the possible costs to Alberta of the FTA, what are the benefits of the FTA that led to an enthusiastic acceptance of the deal by the provincial government? In answering this question, one must consider once again the particular context in which the FTA was concluded. First, there has been an historic desire in the West to escape from the perceived legacy of the National Policy of Sir John A. Macdonald. Under this policy, Western producers sell resource products on world markets at world prices, while Western consumers pay inflated Canadian prices for manufactured goods from Eastern Canada that are produced in the shade of a protective tariff wall.

Apart from this long-standing interest in free trade in Alberta - an interest which was as historically frustrated by the political power of central Canada - there were additional factors motivating the acceptance of this particular FTA. These were rooted in the immediate past experience of the province in its energy relations with Ottawa. The FTA, and especially the chapter relating to energy, was viewed in Alberta not only as a means of increasing the security of access to the U.S. market, but also as a vehicle for wresting substantial control from Ottawa over energy exports and prices. Interestingly, however, the control thus wrested did not devolve to the province, but rather to the market. Not Wares?" in M. Gold \& D. Leyton-Brown, eds., Trade-Offs on Free Trade, The Canada-U.S. Free Trade Agreement (Toronto: Carswell, 1988) 117 at 118. 
only will the FTA make impossible the dirigisme that led to the National Energy Program, it will also limit equivalent intervention by future Alberta governments that may have an interest in limiting the effects of market forces on energy development in the province. In this respect, the FTA reflects not merely the historic desire of Alberta to limit federal intrusion in provincial resource management, but also a commitment to market forces that has not always characterized provincial policies. Whether the market will prove a more agreeable regulator than the federal government in the long run is an open question.

\section{THE STRUGGLE FOR ENVIRONMENTAL CONTROL}

Recently, environmental concerns have emerged as a dominant factor in government decision-making and, as a result, a restructuring of the balance of power between the two levels of government has occurred. While the intensity of the debate over environmental management cannot be compared to the acrimony that accompanied the energy wars, this issue may have far greater potential than the National Energy Program for significant and long-term effects on federal and provincial policy agendas.

The recognition by government, industry and the public at large of the alarming environmental consequences of uncontrolled economic expansion, and of the pressing need to redress environmental deterioration on a national as well as international scale, has affected federal-provincial legislative mandates over resource management in two ways. First, in all resource development and management decisions, consideration of environmental as well as economic factors is a prerequisite; and secondly, provincial ownership of, and conservation and management powers over, natural resources no longer provide justification to the claim by provincial governments that they are the sole, or even the primary, regulators of these resources. In view of the long-range environmental impacts of resource developments and of the failure of most provinces to cope effectively with those impacts, the federal government has assumed, albeit reluctantly, a leading role in responding to environmental challenges.

In the wake of the Brundtland Report in $1987,{ }^{75}$ the Canadian Task Force on Environment and Economy, established by the Canadian Council of Resources and Environment Ministers ("CCREM"), released its own Report ${ }^{76}$ in which a commitment was made to incorporate environmental considerations into economic planning. Having recognized the increasing public demand for information and involvement in the decisionmaking process and the need to bring together all concerned parties, the Task Force recommended the creation of national and provincial Round Tables, "intended to be forums in which decision makers can meet to candidly discuss environment-economy issues and make recommendations directly to the First Ministers of their respective jurisdictions." ${ }^{77}$ The federal as well as all provincial and territorial governments have now created Round Tables. As advisory bodies, they have no binding power over

The World Commission on Environment and Development, Our Common Future (Oxford: Oxford University Press, 1987) (Chair: G.H. Brundtland). of Resources and Environment Ministers, 24 September 1987. 
provincial or federal governments, but their establishment illustrates the role played by factors such as: an emphasis on environmental conservation, consultation processes which allow the public and private sectors to influence policy making and planning, and increased intergovernmental cooperation in environmental management.

In 1988, two further developments - one judicial and the other legislative - signalled the emergence of important changes to the federal role in environmental management. The first was the Supreme Court of Canada judgment in Crown Zellerbach ${ }^{78}$ and the second, the enactment of the Canadian Environmental Protection Act ("CEPA"). ${ }^{79}$

In Crown Zellerbach, the Supreme Court upheld, as an exercise of the Peace, Order and Good Government Power ("POGG"), the constitutionality of section 4(1) of the Ocean Dumping Control Act, ${ }^{80}$ which prohibited the dumping of any substance in the sea except in accordance with the terms and conditions of a permit under the Act. The Court ruled that marine pollution was a single, indivisible matter which qualified as a matter of national concern within POGG, and that federal jurisdiction to regulate it (even in the absence of any proven environmental damage) extended to the regulation of dumping in provincial marine waters. For the dissent, La Forest J. argued that ocean pollution was not a sufficiently discrete subject, and that s. 4(1), which "encompasses activities depositing innocuous substances into provincial waters by local undertakings on provincial lands - that fall within the exclusive legislative jurisdiction of the province, simply overreaches"81 and could not be supported under POGG. La Forest J. warned that the constitutional justification of the impugned provision "would create considerable stress on Canadian federalism as it has developed over the years." ${ }^{82}$

The enactment of the CEPA a few months later confirmed the trend toward an expanding federal role in environmental regulation. The Act consolidated several existing statutes $^{83}$ and extended federal control over the regulation "from cradle to grave" of toxic substances, thereby potentially opening the door to extensive federal regulation of air, water and land pollution. In an analysis of the constitutional validity of the Act, Professor Lucas has concluded that both the criminal law power and POGG provide a constitutional basis for the CEPA, although, based on La Forest J.'s analysis in the Crown Zellerbach case, he questioned whether or not the subject matter of the Act (toxic pollution) has a sufficient distinctiveness. ${ }^{84}$

Despite its potentially far-reaching impact on provincial regulatory powers, the CEPA contains provisions aimed at facilitating cooperation with provincial governments and at

R. v. Crown Zellerbach Canada Ltd. (1989), 3 C.E.L.R. (N.S.) 1 (S.C.C.) [hereinafter Crown Zellerbach].

R.S.C. 1985 (4th Supp.), c. 16.

S.C. $1974-75-76$, c. 55 .

Supra note 78 at 53.

Ibid. at 47.

Including the Clean Air Act, S.C. 1970-71-72, c. 47 (except for s. 4(6), which has not yet been repealed); the Environmental Contaminants Act, S.C. 1974-75-76, c. 72; the Ocean Dumping Control Act, S.C. 1974-75-76, c. 55; and parts of the Canada Water Act, R.S.C. 1970 (1st Supp.), c. 5.

A.R. Lucas, "R. v. Crown Zellerbach Canada Ltd." (1989) 23 U.B.C. L. Rev. 355. 
limiting the scale of federal intrusion into provincial jurisdiction. The equivalency agreement provisions, ${ }^{85}$ which were incorporated into the $A c t$ in order to appease strong provincial and industry objections to the proposed legislation, indicate that the federal government's intention was to establish uniform national standards, while leaving "the bulk of intra-provincial toxic substance regulation in provincial hands. ${ }^{186}$ However, the difficulties associated with implementation have resulted in unilateral federal action in toxic substances regulation. ${ }^{87}$

Two federal initiatives which rapidly followed the enactment of the Act demonstrate the federal governments's intention to make use of its regulatory powers under the CEPA. The first was an interim order regulating the storage of PCBs; the second, an announcement by Environment Canada of its intention to regulate dioxins and furans in pulp and paper mills' effluents. ${ }^{88}$ The Alberta government's reaction is revealed in the following comment from the Alberta Federal and Intergovernmental Affairs' Sixteenth Annual Report:

The fact that the first two regulatory initiatives under the Canadian Environmental Protection Act were taken in provincially regulated areas highlighted the need to resolve roles and responsibilities in environmental management matters. This challenge remains a priority for intergovernmental negotiations. ${ }^{89}$

However, in both cases, intergovernmental negotiations did affect the outcome of the federal decision. The above report acknowledged that "the federal government moved to limit the application of the (PCBs) storage order in those provinces which had regulations of comparable effect to the federal order. ${ }^{190}$ As for the dioxins and furans regulations, their drafting was preceded by extensive consultations between the federal and provincial governments as well as industry and the general public. ${ }^{91}$ The federal government's intention to use its toxic substances regulatory powers under the CEPA was reiterated in

Under s. 34(5) to (10) of CEPA, when provincial laws include provisions similar to the provisions of toxic regulations enacted under CEPA, the federal Minister of the Environment and the government of that province may agree in writing that provincial laws are equivalent and that the CEPA regulations do not apply in the province. See also s. 6 (federal-provincial advisory committee) and s. 98 (federal-provincial agreements). Supra note 84 at 366.

See A.R. Lucas, "Jurisdictional Disputes: Is "Equivalency" A Workable Solution," in D. Tingley, ed., Into the Future: Environmental Law and Policy for the 1990s (Edmonton: Environmental Law Centre, 1990) at 25.

The announcement was followed, in April 1990, by the release of Draft Regulations respecting the release of chlorinated dibenzo-para-dioxins and chlorodibenzofurans in effluents from pulp and paper mills. The Pulp and Paper Mill Effluent Chlorinated Dioxins and Furans Regulations received final approval on 7 May 1992 (SOR/92-268). Alberta Federal and Intergovernmental Affairs, Sixteenth Anmual Report to March 31, 1989, at 18. Ibid.

Further, certain provinces, including Alberta, took immediate steps to impose on their pulp and paper industry new standards for dioxins and furans emissions, thus moving ahead of the federal government. See "Alberta Set to Toughen Pulp and Paper Standards" (1989) 6:1 Eco/Log Monthly Report 2. 
the recently published Green Plan, which outlines an action plan for the control of toxic substances to be implemented over the next five years. ${ }^{92}$

Perhaps the most significant threat to the traditional federal-provincial balance of power in natural resources management has arisen from the increasing use of the federal Environmental Assessment Review Process ("EARP"). ${ }^{93}$ Environmental Impact Assessment ("EIA") processes, which attempt to identify and address the potential environmental impacts of projects at the early stages of planning, have become critical tools in the integration of economic and environmental considerations. As a result of a series of Federal Court decisions in 1989 and $1990,{ }^{94}$ establishing the legally binding nature of the EARP and expanding the scope of its application, concerns were strongly expressed by provincial governments that projects which were previously considered primarily subject to provincial jurisdiction would become subject to federal environmental review. In Premier Getty's words, "if there's a fish anywhere around in some water, the federal government gets to control what happens. ${ }^{195}$ Indeed, the sudden increase in the number of proposals submitted to public review under the EARP since 1989 appears to confirm the fears of provincial governments.

The potential impact of federal EIA processes was of most concern to provincial natural resources ministries. For example, following the enactment of the federal Department of Forestry Act, ${ }^{96}$ Alberta Forestry, Lands and Wildlife, in a brief submitted to the Commons Sub-Committee on Forestry, ${ }^{97}$ indicated that, in recently signed Forest Resource Development Agreements ("FRDA") - cost-sharing agreements supporting a diversity of forest management programmes - the federal government had substantially expanded its control over the administration of the programmes. The brief further emphasized that "making all projects with any federal funding subject to federal Environmental Assessment and Review guidelines...could potentially open the door to federal hearings on how a province conducts its forest management programmes, simply because that province accepted a cost-shared stand tending programme under FRDA."18

Government of Canada, Canada's Green Plan (Ottawa: Minister of Supply and Services Canada, 1990) at $46-47$.

As established by the Environmental Assessment and Review Process Guidelines Order, SOR/84-467, pursuant to s. 6(2) of the Government Organization Act, 1979, S.C. 1978-79, c. 13.

The Federal Court decisions relate to two major court cases, both involving the construction of dams: the Rafferty-Alameda dams in southern Saskatchewan, and the Oldman River dam in southern Alberta. Sec Canadian Wildlife Federation Inc. v. Canada (Minister of the Environment), [1989] 4 W.W.R. 526; aff'd [1990] 2 W.W.R. 69 (F.C.A.D.); and Friends of the Oldman River Society v. Canada (Minister of Transport, and Minister of Fisheries and Oceans), [1991] 1 W.W.R. 352 (F.C.A.D.), rev'g (1989), [1990] 2 W.W.R. 150 (F.C.T.D.) [hereinafter Oldman River]. However, it is noteworthy that, in contradistinction to federal actions during the energy wars, the federal government was not the initiator of these actions; in both cases the federal government was forced to act as the result of lawsuits launched by private citizens, who demanded that federal authorities comply with their regulatory duties. decision in Oldman River, submitted to the Supreme Court of Canada on April 18, 1990, at 205.

S.C. 1989 , c. 27.

Dated 28 May 1990.

Ibid. at 10. 
In Alberta Forestry's opinion, Forestry Canada's role was to be restricted to traditional areas, such as international trade or applied research and technology transfer, and the department should "avoid using the federal spending power in a coercive way," which would be "incompatible with the department's responsibility for fostering cooperation."

Similarly, provincial and territorial Energy Ministers, in a 1990 joint communiqué, ${ }^{100}$ requested the federal government to "take immediate action to remove the uncertainties associated with these [EARP] guidelines" pending the enactment of the Canadian Environmental Assessment Act ("CEAA"). ${ }^{101}$ The Ministers also suggested that, in order to avoid duplication, the new Act provide for the substitution of comparable provincial or territorial review processes.

It is in this expanding field of federal review of provincial resource developments that Alberta reacted most strongly to perceived federal "intrusions" into provincial matters and took the initiative to challenge their constitutionality. Following the Federal Court of Appeal ruling in the Oldman River, ${ }^{102}$ the Alberta government launched an appeal which was heard in February 1991 in the Supreme Court of Canada. Stressing the national importance of the case and its impact on the future of major projects across Canada, the Alberta government questioned, in particular, the constitutionality of certain sections of the Guidelines Order which authorized the EARP, and the application of the process to projects of the Government of Alberta or any other undertaking "primarily subject to provincial jurisdiction." The decision of the Supreme Court ${ }^{303}$ addressed the constitutional question at length. La Forest J., writing for the majority, found that the Guidelines Order was intra vires Parliament:

In the end, I am satisfied that the Guidelines Order is in pith and substance nothing more than an instrument that regulates the manner in which federal institutions must administer their multifarious duties and functions. Consequently, it is nothing more than an adjunct of the federal legislative powers affected. ${ }^{104}$

Responding to the concern expressed by provincial governments that the Guidelines Order could be a "constitutional Trojan horse enabling the federal government, on the pretext of some narrow ground of federal jurisdiction, to conduct a far ranging inquiry into matters that are exclusively within provincial jurisdiction, ${ }^{n 105}$ La Forest J. specified that there had to be a direct link between the matters examined and the area of federal responsibility affected. The Guidelines Order could not be used "as a colourable device to invade areas of provincial jurisdiction which are unconnected to the relevant heads of

Ibid. at 16.

Meeting of the Council of Provincial Ministers of Energy, Winnipeg, Manitoba, 27 August 1990. The Act received Royal Assent on 23 June 1992 (S.C. 1992, c. 37) and awaits proclamation. Supra note 94.

[1992] 2 W.W.R. 193 (S.C.C.). The case was decided by an 8-1 majority, with the lone dissent coming from Stevenson J., formerly of the Alberta Court of Appeal; moreover the dissent did not take issue with the finding of the majority regarding the constitutional questions posed by the case. Ibid. at 246.

Ibid. at 243. 
federal power. ${ }^{106}$ Nevertheless, once the process has been engaged, the scope of the assessment is not confined to one particular head of power. On the contrary, the initiating department must consider the environmental effect on all areas of federal jurisdiction.

La Forest J. determined that the characterization by Alberta of the Oldman River dam as a provincial project "primarily subject to provincial regulation" was not particularly useful in that "it begs the question and posits an erroneous principle that seems to hold that there exists a general doctrine of interjurisdictional immunity to shield provincial works or undertakings from otherwise valid federal legislation." ${ }^{107}$ Having established the constitutional validity of the Guidelines Order, he concluded that "any intrusion into provincial matters is merely incidental to the pith and substance of the legislation." 108

The Supreme Court decision clearly establishes the constitutionality of the federal review process and its applicability to provincial projects. However, the judgment defined the ambit of the federal review process more narrowly than earlier Federal Court decisions. The Guidelines Order does not apply every time a project may have an environmental impact on an area of federal jurisdiction. In order for a project to qualify as a "proposal", the federal department concerned must have a "decision-making responsibility", which Justice La Forest construed as an "affirmative regulatory duty" pursuant to a federal statute. A federal statute such as the Fisheries $A c t^{109}$ does not impose an affirmative regulatory duty upon the Minister, only a legislative power with respect to works or undertakings. As a result, the Minister of Fisheries is not bound by the Guidelines Order. Such an interpretation restricts to a large extent the range of provincial projects which were thought to be subject to a federal review on the basis of earlier interpretations by the Federal Court of Appeal.

Despite the existence of tensions between the federal government and Alberta over the past five years, due mainly to the uncertainties associated with the scope of environmental jurisdiction of each level of government, increasing cooperation by Alberta, both with other provinces and territories and with the federal government, is noticeable. Similar to many of its provincial counterparts, and in response to both public and federal pressure, Alberta has taken unprecedented measures to update and remodel its environmental legislation. ${ }^{110}$ The new Environmental Protection and Enhancement Act ("EPEA") includes provisions for investigation of alleged offences, the intent of which is to facilitate the negotiation with the federal government of equivalency agreements under the CEPA. ${ }^{11}$ Further, the EPEA and the Natural Resources Conservation Board Act, ${ }^{112}$

\footnotetext{
100 Ibid.

107 Ibid. at 241.

tos Ibid. at 246.

109 R.S.C. 1985 , c. F-14.

110 The Natural Resources Conservation Board Act, S.A. 1990, c. N-5.5 was proclaimed 3 June 1991; the Environmental Protection and Enhancement Act, S.A. 1992, c. E-13.3 (a consolidation of nine existing environmental acts), was assented to June 26, 1992 and came into force on Proclamation September 1, 1993. The Water Resources Act, R.S.A. 1980, c. W-5 is being reviewed separately. These are ss. 184 and 185 of the $A c t$, which are almost identical to ss. 108 and 109 of the CEPA, and allow two persons who are of the opinion that an offence is being committed under the Act to apply to the Director for an investigation of the alleged offence.
} 
which establishes detailed procedures and a new board for the conduct of environmental impact assessments of provincial projects, both provide for interjurisdictional cooperation in environmental assessment matters.

The cooperative mood of the Alberta government is best described in a document entitled Statement of Interjurisdictional Cooperation on Environmental Matters, adopted in March 1990 by the Canadian Council of Ministers of the Environment ("CCME"). The Statement recognizes two fundamental realities: first, legislative authority to regulate environmental matters is shared by the federal and provincial governments, and second, environmental concerns and impacts cross physical and political boundaries. The necessity of interjurisdictional cooperation is affirmed together with an enumeration of fundamental principles of cooperation.

A subsequent document, the Western Accord on Environmental Cooperation, was adopted at a February 1991 meeting of Western provincial and territorial Ministers of Environment, Energy and Natural Resources. It reiterates the commitment to environmental cooperation by promoting the development of bilateral agreements and cooperative principles for environmental assessments. ${ }^{113}$ In May 1991, these principles were formally adopted by the CCME ${ }^{114}$ In addition, the CCME developed and submitted to the House of Commons legislative committee on the proposed Canadian Environmental Assessment Act a set of amendments providing for the joint determination of the level of federal and provincial participation in areas of overlapping jurisdiction, and for the ability to defer to an equivalent provincial review process. ${ }^{115}$

The extent to which the province of Alberta is willing to submit to the recommendations of a jointly appointed review board may, however, be limited. A recent example of federal-provincial cooperation is provided by the assessment of the proposed Alberta-Pacific pulp and paper mill in $1990 .{ }^{116}$

\section{CONCLUSION}

Issues related to the management of natural resources have played an important role in federal-provincial relations over the past quarter century. Given the importance of

S.A. 1990 , c. N-5.5.

On August 6, 1993, the Alberta and federal governments signed an agreement on the harmonization of environmental assessments; see Canada-Alberta Agreement for Environmental Assessment Cooperation. Interested parties were invited to comment on a draft of the agreements.

114

115
Canadian Council of Ministers of the Environment, Communiqué, Halifax, 6 May 1991.

Amendments to Bill C-78, An Act to Establish a Federal Environmental Assessment Process, a Submission to the House of Commons Legislative Committee on Bill C-78 by the Ministers of Environment of British Columbia, Alberta, Saskatchewan, Manitoba, Ontario, New Brunswick, Prince Edward Island, Nova Scotia, Newfoundland, Yukon, Northwest Territories, presented by the Honourable John Reynolds, Minister of Environment for British Columbia, 4 December 1990. The provincial proposals to insert in the Bill provisions for deferral to an equivalent provincial process were resisted by the federal government.

The joint review of the proposed Alberta-Pacific (Al-Pac) pulp mill was completed in March 1990. See Alberta Environment, The Proposed Alberta-Pacific Pulp Mill: Report of the EIA Review Board (Edmonton: Alberta Environment, 1990). 
Alberta as a producer of natural resources - and particularly as the dominant producer of energy resources in Canada - it is perhaps not surprising that Alberta's role in the evolution of federalism over that period has been disproportionate to its population. The Alberta position in the various debates over natural resources management cannot, however, be reduced to a simplistic ideological stance of, for example, a consistent adherence to provincial rights or a firm commitment to market mechanisms.

The first prerequisite to understanding Alberta's policies is the historical context, a context that differs significantly from that in Eastern Canada, where ownership of natural resources was carried by the different provinces into Confederation. The twenty-five year struggle to acquire control over resources in Western Canada has left a residue of suspicion that informs natural resources policy in Alberta to the present day. That suspicion has been reinforced by measures such as the National Energy Program of 1980.

Thus, federal measures that threaten to impinge on the province's ability to set its own priorities in this area have typically been regarded with suspicion, if not outright hostility. This was true in the case of the federal appropriation of energy rents in the 1970s and 1980s, and has been the case most recently with respect to environmental management, where federal assessments of projects relating to water development (the Oldman Dam) and pulp and paper (Al-Pac) have led to intense provincial opposition, despite a clear federal jurisdictional interest.

Alberta's aversion to federal intervention, however, is not fully explained by the obvious desire to control the pace of exploitation and to garner the full financial rewards of resource development. There is also an underlying belief that federal officials in Ottawa are simply unequipped to serve the particular needs of the province, even assuming they are sympathetic to them. This refrain was a common theme during the energy wars, especially with respect to some of the measures instituted under the National Energy Program. More recently, the charge of insensitivity by national bureaucrats to the particular needs of the province has been asserted vigorously in the context of environmental management.

It would be too simple to characterize suspicion of federal actions in the area of natural resources management as ideological in the sense of a rigid insistence on a doctrine of "provincial rights". It is noteworthy, for example, that the resources amendment to the Constitution (s. 92A) was not a major item on Alberta's constitutional agenda, presumably because the practical gains from such a measure were not great. Alberta's positions on federalism have rather been informed by a strong sense of pragmatism: where the National Oil Policy of the pre-1973 period was coincident with the province's own immediate interests, there was no objection to federal control in this area; where the National Energy Program was hostile to those interests, Alberta adopted a strongly provincialist stance.

This theme of pragmatism also runs through Alberta's varying degrees of attachment to the market as a regulator of natural resources trade. When the market has been perceived as an alternative to disadvantageous federal pricing and export policies, Alberta has taken up the banner of the invisible hand. However, the province itself has displayed no reluctance over the longer run to intervene heavily in the energy sector where it 
perceived its interests were at stake. It is an open question whether the province's willingness to embrace market forces under the Free Trade Agreement, (as the price for precluding a range of future federal measures in the energy sector), will be as great in the future when the full consequences of the limitations on provincial actions become clear. 